\title{
PERSONAL HYGIENE DENGAN METODE SPY KEPADA ORANG TUA SISWA SLB-C NEGERI PEMBINA DI LANDASAN ULIN BARAT
}

\author{
Pandji Winata Nurikhwan'), Hadrianti H. D. Lasari'2), Mohammad Bakhriansyah¹) \\ 1)Program Studi Kedokteran, Fakultas Kedokteran, Universitas Lambung Mangkurat, Banjarmasin, Kalimantan Selatan, \\ Indonesia \\ 2)Program Studi Kesehatan Masyarakat, Fakultas Kedokteran, Universitas Lambung Mangkurat, Banjarmasin, \\ Kalimantan Selatan, Indonesia \\ Corresponding author: Hadrianti H. D. Lasari \\ E-mail: hadriantilasari@gmail.com
}

Diterima 18 November 2021, 03 Desember 2021, Disetujui 03 Desember 2021

\begin{abstract}
ABSTRAK
Penyandang disabilitas dengan berbagai hambatan yang mereka miliki dapat mengalami berbagai hambatan dapat menghalangi partisipasi mereka secara penuh dan efektif di dalam masyarakat. SLBC Negeri Pembina Kalimantan Selatan merupakan salah satu wadah untuk membantu anak-anak tunagrahita dalam proses meningkatkan kemampuan intelegensi mereka. Karena minimnya pengetahuan tentang personal hygiene pada murid penyandang disabilitas, SLB-C Negeri Pembina Kalimantan Selatan menjadi fokus untuk mengadakan kegiatan edukasi tidak hanya untuk anak murid SLB-C Pembina Kalimantan Selatan tetapi juga orang tua serta staff terkait. Pelaksanaan kegiatan ini diimplementasikan dengan perpaduan secara luring dan daring menggunakan metode SPY (seminar, practice, apply) yang terdiri dari pendekatan (bonding) dengan pihak mitra, kemudian dilanjutkan dengan acara puncak dalam satu hari dengan agenda pre-test, seminar Personal hygiene Fun-Edu, post-test, peragaan dan praktik, serta penutupan. Kegiatan terakhir yaitu melakukan monitoring terhadap progress mitra yaitu orang tua dari anak-anak tunagrahita dalam mengaplikasikan personal hygiene.
\end{abstract}

Kata kunci: tunagrahita; personal hygiene; cuci tangan

\begin{abstract}
Persons with disabilities with various barriers that they have can experience various obstacles that can prevent their full and effective participation in society. SLB-C Negeri Pembina South Kalimantan is a forum to help mentally retarded children in the process of improving their intelligence abilities. Due to the lack of knowledge about personal hygiene for students with disabilities, SLB-C Negeri Pembina South Kalimantan became the focus to hold educational activities not only for SLB-C Pembina South Kalimantan students but also parents and related staff. The implementation of this activity is implemented by combining offline and online using the SPY method (seminar, practice, apply) which consists of an approach (bonding) with partners, then followed by a peak event in one day with a pretest agenda, a seminar on Personal hygiene Fun- Edu, post-test, demonstration and practice, and closing. The last activity is monitoring the progress of partners, namely parents of mentally retarded children in applying personal hygiene.
\end{abstract}

Keywords: mental retardation; personal hygiene; hand washing.

\section{PENDAHULUAN}

Menurut United Nation Convention on the Rights of Persons with Disabilities (UNCRPD), penyandang disabilitas yaitu mereka yang memiliki gangguan jangka panjang secara fisik, mental, intelektual, atau sensorik yang dalam interaksinya dapat menghalangi partisipasi penuh dan efektif mereka di dalam masyarakat atas dasar kesetaraan dengan yang lainnya. Menyusul pengesahan Indonesia atas UNCRPD pada tahun 2011, UU Nomor 8 Tahun 2016 mengenai Penyandang Disabilitas menggantikan semua undang-undang terdahulu tentang hak-hak disabilitas, yang menciptakan klasifikasi formal yang sesuai dengan standar internasional: fisik, mental, intelektual, dan sensorik. Disabilitas fisik adalah terganggunya fungsi gerak, antara lain amputasi, lumpuh layuh atau kaku, paraplegi, celebral palsy (CP), akibat stroke, akibat kusta, dan orang kecil. Disabilitas mental adalah terganggunya fungsi pikir, emosi, dan perilaku, antara lain skizofrenia, bipolar, depresi, anxietas, gangguan kepribadian, autis dan hiperaktif. Disabilitas intelektual adalah terganggunya fungsi pikir karena tingkat 
kecerdasan di bawah rata-rata, antara lain meliputi lambat belajar, disabilitas grahita dan down syndrome. Disabilitas sensorik adalah terganggunya salah satu fungsi dari panca indera, antara lain disabilitas netra, disabilitas rungu, dan/atau disabilitas wicara (Asterina dkk., 2019).

Tunagrahita merupakan suatu kondisi dimana anak memiliki kecerdasan yang berada di bawah rata-rata dan ditandai dengan keterbatasan intelegensi maupun ketidakcakapan terhadap komunikasi sosial. Keterbatasan intelegensi pada anak tunagrahita mengakibatkan rendahnya kemampuan anak dalam proses belajar, dan juga dalam hal belajar untuk perawatan dirinya. Anak tunagrahita memiliki intelegensi di bawah normal dengan skor IQ sama dengan atau lebih lebih rendah dari 70 . Kemampuan anak tunagrahita berbeda dengan anak yang lain tergantung tingkat intelegensinya. Selain itu, mereka seringkali mengalami kendala dalam kemampuan melakukan Activity Daily Living (ADL) atau aktivitas sehari-hari agar seseorang dapat berfungsi dalam kehidupan sehari-hari, seperti makan, berpakaian, menjaga kebersihan diri, dan buang air. Maka dari itu, dukungan keluarga sangat dibutuhkan oleh anak berkebutuhan khusus ini (Pursitasari dkk., 2020).

Dukungan yang paling umum untuk anak dengan disabilitas adalah materi/instrumental, dimana keluarga menyediakan kebutuhan dasar seperti pangan, papan, dan perawatan kesehatan. Peran dan dukungan keluarga terutama orang tua sangat dibutuhkan untuk membantu kemandirian anak berkebutuhan khusus. Peran pengasuhan anak tunagrahita dan dukungan keluarga dan sosial masih rendah yaitu masing-masing sebesar 16,1\% dan $12,9 \%$. Penelitian lain menyebutkan bahwa persentase anak tunagrahita mampu melakukan kegiatan perawatan diri (personal hygiene, makan, minum, berpakaian, mobilisasi, gerak, sosialisasi) tanpa bantuan orang lain adalah hanya $3,1 \%$. Meskipun sebuah penelitian berbeda menyebutkan bahwa kemampuan anak tunagrahita ke toilet adalah $45,5 \%$, anak tunagrahita sangat bergantung pada orang tua dan guru untuk melakukan BAB dan persalinan pakaian (Teixeira dkk., 2015).

Perawatan diri atau personal hygiene sangat penting bagi anak karena seringkali anak terkena penyakit akibat tidak memperhatikan tentang personal hygiene. Pengetahuan personal hygiene harus diberikan sejak dini yang tujuannya agar pengetahuan anak tentang kebersihan diri akan lebih matang, sehingga anak akan terbiasa untuk melakukan personal hygiene. Lazimnya personal hygiene pada anak usia sekolah 7-12 tahun meliputi kebersihan tangan, kuku, dan baju (Triasmari dkk., 2019). Perawatan diri yang baik berdampak pada kesehatan meskipun status kesehatan penyandang disabilitas lebih rendah daripada kesehatan secara umum. Masalah lain yang muncul karena kurangnya perawatan diri adalah ketidaknyamanan yang disebabkan oleh pakaian kotor karena ketidakmampuan ke toilet. Selain itu, anak berkebutuhan khusus seringkali menjadi korban perundungan (bullying), baik secara fisik maupun verbal (Pursitasari dkk., 2020).

Pada masa pandemi Covid-19 seperti saat ini, kesehatan menjadi semakin sulit diakses yang berdampak bagi banyak orang termasuk anak-anak tunagrahita. Adanya Covid-19 sangat dirasakan dampaknya pada anak tunagrahita khususnya di Banjarmasin yang memiliki masalah perkembangan, yaitu bagaimana memberikan prioritas kesehatan bagi anak tunagrahita dan layanan pendidikan yang berkualitas. Mereka membutuhkan pendampingan. Anak tunagrahita memiliki risiko penularan penyakit yang tinggi apabila tidak ada pendampingan terkait masalah kesehatan (Pursitasari dkk., 2020). Terkait masalah perkembangan, guru dan sekolah perlu mengetahui cara mentransformasikan pembelajaran menjadi media daring (online). Ketika di rumah, terdapat tiga komponen yang merupakan tantangan yang dihadapi anak tunagrahita, yaitu guru, orangtua mau pun keluarga, dan anak tunagrahita itu sendiri. Tantangannya adalah bagaimana guru dapat mendampingi anak belajar selama masa pandemi ini karena anak akan lebih mudah mengalami stres (Safaria dkk., 2015 dan Wanei dkk., 2015).

Sekolah Luar Biasa khusus Tunagrahita (SLB-C) menjadi salah satu wadah untuk membantu anak-anak tunagrahita dalam proses meningkatkan kemampuan intelegensi dan perawatan dirinya. SLB-C Pembina yang berlokasi di Jl. A.Yani Km. 20 Landasan Ulin Barat Kota Banjarbaru, Provinsi Kalimantan Selatan, Indonesia dan didirikan sejak 1991 terus membenahi diri dengan menerapkan sistem kurikulum TKLB 2013. Sekolah ini memiliki beragam fasilitas untuk menunjang pembelajaran. Dengan manajemen berbasis sekolah yang terdiri dari 103 ruang kelas, 1 perpustakaan, 6 ruang sanitasi siswa, banyaknya pusat lembaga kebudayaan terdekat serta 65 orang guru menjadikan SLBC Pembina berkompeten dalam membina 239 siswanya. Sekolah ini memiliki ketertarikan pada pembelajaran personal hygiene anakanak tunagrahita. Maka dari itu, kami Tim PKM Pengabdian Masyarakat ingin membantu untuk 
memecahkan beberapa permasalahan terkait optimalisasi peran orang tua dan guru dalam membantu kemampuan beradaptasi para penyandang tunagrahita di tengah pandemi Covid-19. Sasaran program ini adalah anakanak tunagrahita di SLB-C Pembina Kalimantan Selatan. Pemilihan sasaran didasarkan karena komunitas diarahkan untuk komunikasi, informasi dan edukasi terkait dengan pendidikan kesehatan selama pandemi. Promosi dan edukasi kesehatan serupa dapat dilanjutkan oleh pihak sekolah, atau pelayanan lainnya, agar dapat meningkatkan kemampuan adaptasi anak tunagrahita, bukan hanya saat kondisi pandemi tetapi diharapkan dapat diterapkan seterusnya.

\section{METODE}

Kegiatan PKM-PM ini dilaksanakan dengan semi-luring (blended method). Mengingat pandemi Covid-19, pelaksanaan kegiatan PKM akan diimplementasikan dengan perpaduan secara luring (offline) dan daring. Kegiatan secara luring dilakukan dengan memperhatikan protokol kesehatan yang berlaku, sedangkan pelaksanaan kegiatan secara daring dilakukan dengan menggunakan media seperti YouTube, dsb untuk mengantisipasi peserta yang tidak bisa berhadir secara langsung.

Para peserta akan mendapatkan bingkisan atau souvenir. Untuk menyempurnakan kegiatan dengan menggunakan metode SPY (seminar, practice, apply) ada beberapa hal yang harus dilaksanakan dalam jangka waktu yang telah diusulkan, yaitu

1. Pendekatan (Bonding) dengan Pihak Mitra Pendekatan dengan pihak mitra diadakan satu kali pada 7-10 hari sebelum acara puncak yang diadakan secara luring. Hal ini bertujuan untuk menciptakan hubungan yang lebih erat dan saling mengerti antara pihak mitra dan penyelenggara. Agenda kegiatan ini berupa agenda sharing dimana pihak mitra menyampaikan permasalahan terkait yang akan dibawa maupun isu-isu lain kepada pihak penyelenggara dengan harapan pihak penyelenggara dapat membantu memecahkan permasalahan tersebut.

\section{Acara Puncak}

Acara ini diadakan dalam satu hari pada tanggal yang telah disepakati, dengan agenda:

\section{a. Pre-test}

Pada hari kegiatan, guru dan wali murid yang akan diberikan pelatihan diberikan beberapa pertanyaan terkait perilaku hidup bersih dan sehat (PHBS) dan personal hygiene sebelum pemaparan materi melalui seminar. Pre-test dilakukan untuk mengetahui pengetahuan awal peserta mengenai aspekaspek yang berhubungan dengan perilaku hidup bersih dan sehat. Pre-test juga bertujuan agar selama acara lebih tercipta hubungan interaktif antara peserta dan pembicara. Pretest diberikan melalui G-form untuk peserta yang berhadir secara daring dan kertas yang telah disediakan untuk peserta yang berhadir secara luring.

\section{b. Personal hygiene Fun-Edu Seminar}

Personal hygiene Fun-Edu merupakan singkatan dari personal hygiene fun education dimana pendekatan kegiatan yang diupayakan adalah dengan memberdayakan orang tua dari anak-anak penderita tunagrahita dalam perannya untuk melatih anak-anak penderita tunagrahita dalam menjaga kebersihan dirinya. Pengetahuan mengenai personal hygiene sejak dini adalah hal yang penting dalam mencapai tujuan kegiatan ini. Karena itu seminar akan diberikan oleh para pembicara yang sudah berpengalaman dalam topik personal hygiene dan terutama bagaimana pendekatan yang menyenangkan untuk mengajarkannya secara mandiri kepada anak-anak penderita tunagrahita. Dikarenakan masa pandemi Covid19 ini, seminar dibagi menjadi dua bagian dalam waktu yang bersamaan yaitu secara daring dan secara luring dengan mengikuti protokol kesehatan yang ada. Jadi pihak-pihak yang tidak bisa mengikuti acara secara langsung masih bisa mengikuti materi yang ingin disampaikan.

c. Post-test

Post-test dilakukan setelah peserta mendapatkan pemaparan materi untuk mengevaluasi apakah peserta dapat memahami materi yang telah diberikan. Peserta diberikan beberapa pertanyaan terkait aspek PHBS. Post-test dilakukan untuk mengetahui peningkatan pengetahuan pada peserta setelah pelatihan. Test ini diberikan melalui G-form dan kertas yang telah disediakan.

d. Peragaan dan Praktik

Dalam bagian acara ini diperagakan bagaimana melakukan cuci tangan yang baik dan benar dalam menjaga personal hygiene kepada murid-murid SLB-C Negeri Pembina Kalimantan Selatan.

\section{e. Penutup}

Di kegiatan diadakan acara penutupan. Tim yang sudah berada di lokasi mitra memberikan souvenir untuk murid-murid SLB C Negeri Pembina Kalimantan Selatan untuk meningkatkan kesadaran akan PHBS dan juga sebagai wujud apresiasi. Acara ini juga untuk merangkum kegiatan yang sudah dilaksanakan dan pendokumentasian kegiatan. 


\section{Monitoring progress mitra}

Untuk mengetahui proses yang telah diterapkan oleh orang tua dari anak-anak penderita tunagrahita dalam perannya untuk melatih anak-anak penderita tunagrahita dalam menjaga kebersihan dirinya, pihak penyelenggara mengadakan Video Challenge. Orang tua murid mengabadikan perkembangan personal hygiene pada anak-anaknya. Pada Video Challenge ini dipilih 3 pemenang dengan video terbaik yang mendapatkan hadiah yang telah disediakan. Video Challenge ini diadakan 1 bulan setelah acara puncak dengan interval waktu kurang lebih 1 minggu.

\section{HASIL DAN PEMBAHASAN}

a. Pendekatan (Bonding) dengan Pihak Mitra

Tim pengabdian masyarakat FK ULM terlebih dahulu melakukan pertemuan virtual via platform Zoom untuk membahas rancangan kegiatan yang akan dilaksanakan, mendiskusikan beberapa tema kegiatan yang diusulkan oleh tim penyusun, sasaran kegiatan, dan menentukan mitra kegiatan yang akan dilaksanakan. Kesimpulan dari pertemuan yang dilaksanakan adalah merancang kegiatan Pembinaan Personal Hygiene dengan Metode SPY kepada Orang Tua, dan mitra yang terpilih adalah SLB Banjarbaru.

Setelah tim penyusun menentukan mitra, selanjutnya adalah meminta persetujuan dari SLB-C Negeri Pembina Kalimantan Selatan untuk bekerjasama menjadi mitra dalam kegiatan. Tim penyusun menghubungi Wakil Kepala Sekolah bagian Hubungan Masyarakat SLB-C Negeri Pembina Kalimantan Selatan, Bapak Sihadi M.Pd, dan berkoordinasi mengenai alur dan tata cara mendapatkan persetujuan. Tim abdimas berkunjung ke lokasi SLB-C Negeri Pembina Kalimantan Selatan untuk bertemu dengan Kepala Sekolah SLB-C Negeri Pembina. Tim menjelaskan kepada Kepala Sekolah SLB-C mengenai rancangan kegiatan yang akan dilaksanakan dan sekaligus meminta persetujuan. Kepala sekolah memberikan respon yang antusias dan menantikan acara yang akan dilaksanakan.

Pada kesempatan tersebut, pihak sekolah menyetujui kegiatan yang akan dilaksanakan dan memberikan persetujuan dengan mengisi surat pernyataan program kegiatan pengabdian masyarakat. Tim kembali melakukan pertemuan virtual via platform Zoom untuk membentuk kepanitiaan. Pada pertemuan ini juga dibahas mengenai kebijakan administrasi, surat-menyurat dan rancangan keuangan untuk pelaksanaan kegiatan. Kemudian tim penyusun menindaklanjuti kegiatan yang telah disusun. Tim abdimas mendiskusikan waktu kegiatan seminar bersama dengan Wakil Kepala
Hubungan Masyarakat SLB-C Negeri Pembina via WhatsApp chat dan disepakati seminar pertama untuk abdimas personal hygiene dengan topik "Always Be Clean" dilaksanakan pada hari Kamis, 23 September 2021 dan seminar kedua pada hari Minggu, 3 Oktober 2021.

Kegiatan bonding dilakukan secara luring di SLB-C Negeri Pembina Kalimantan Selatan. Pada kegiatan tersebut, tim abdimas memaparkan rangkaian kegiatan yang akan dilakukan bersama mitra yang diwakili oleh Wakil Kepala Humas SLB-C Negeri Pembina. Kemudian tim berdiskusi dan sharing terkait kegiatan seminar, serta melakukan survei lokasi seminar.

Selanjutnya, narahubung berkomunikasi dengan Kepala Sekolah dan Wakil Kepala Sekolah SLB-C Negeri Pembina Kalimantan Selatan melalui WhatsApp call. Narahubung dan Kepala Sekolah mendiskusikan tentang target sasaran kegiatan serta memberikan masukan agar kegiatan yang akan dilaksanakan lebih menarik minat untuk orangtua siswa.

Untuk itu pihak SLB-C dan panitia kegiatan menyepakati bahwa selain kegiatan seminar, satu jam sebelum kegiatan akan dilakukan pemeriksaan kesehatan berupa pemeriksaan tekanan darah dan pemeriksaan gula darah. Agar kegiatan berjalan dengan lancar dan dapat menjalankan kebijakan melakukan acara secara luring sesuai dengan protokol kesehatan Covid-19, peserta seminar dibatasi maksimal 60 peserta dari kalangan orangtua untuk menyesuaikan dengan luas ruangan yang tersedia di sekolah. Dua hari sebelum seminar pertama dilaksanakan, Wakil Kepala Sekolah Hubungan Masyarakat SLB-C Negeri Pembina melalui chat WhatsApp menginfokan tentang undangan untuk kegiatan seminar pertama sesuai dengan kesepakatan yang telah didiskusikan sebelumnya.

\section{b. Tahap Pra Pelaksanaan}

Tim abdimas membuat sosialisasi berbasis Instagram. Poster seminar pertama dan kedua diunggah dengan memuat topik bahasan, pembicara, dan waktu pelaksanaan seminar. Untuk seminar pertama "Kebersihan Diri (Mencuci Tangan dan Mandi)", dilaksanakan pada hari Kamis, 23 September 2021 pukul 08.00 - 11.25 WITA dengan dr. Elma Rusida sebagai pembicara. 


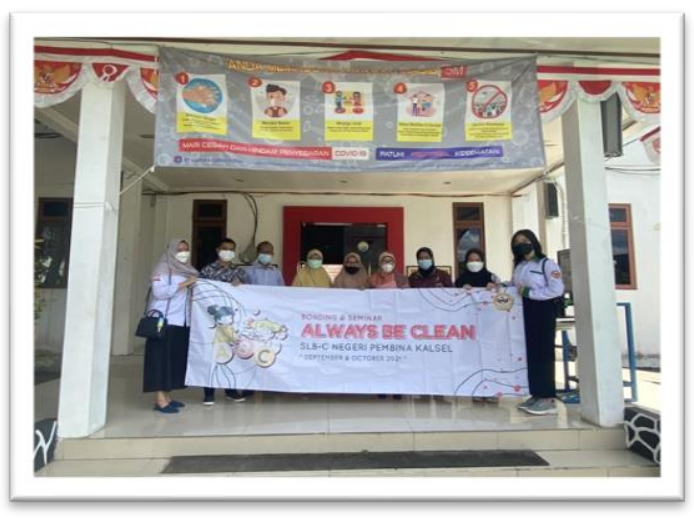

b. Tahap pelaksanaan seminar pertama

Kegiatan ini diawali dengan proses registrasi peserta seminar dengan mengikuti panduan mengadakan acara secara luring di era pandemi Covid-19. Sebelum melakukan cek kesehatan, peserta mencuci tangan dan diukur suhu tubuhnya untuk kemudian diarahkan ke meja pemeriksaan. Total peserta saat registrasi yaitu 100 peserta ditambah panitia dan undangan.

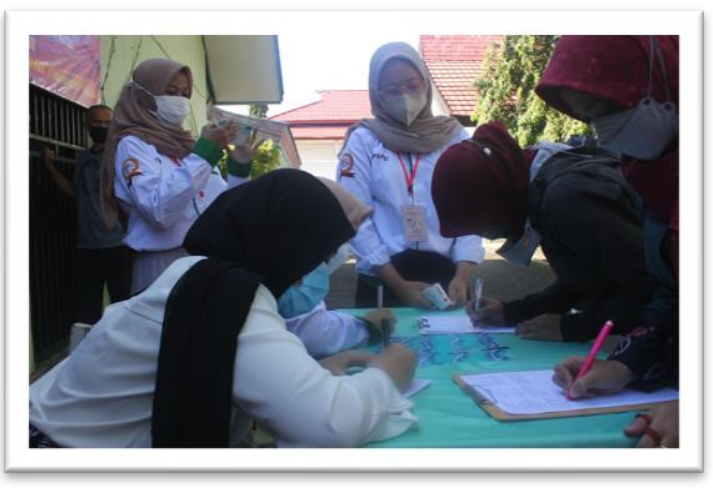

Tetap taat protokol Kesehatan pada masa pandemi Covid-19, tim abdimas melakukan pengecekan kesehatan yang dilakukan panitia. Pengecekan yang dilakukan yaitu pengecekan tekanan darah (tensi) dan pengecekan kadar gula darah. Pada kesempatan tersebut, murid juga diberikan souvenir berupa sikat gigi dan pasta gigi.

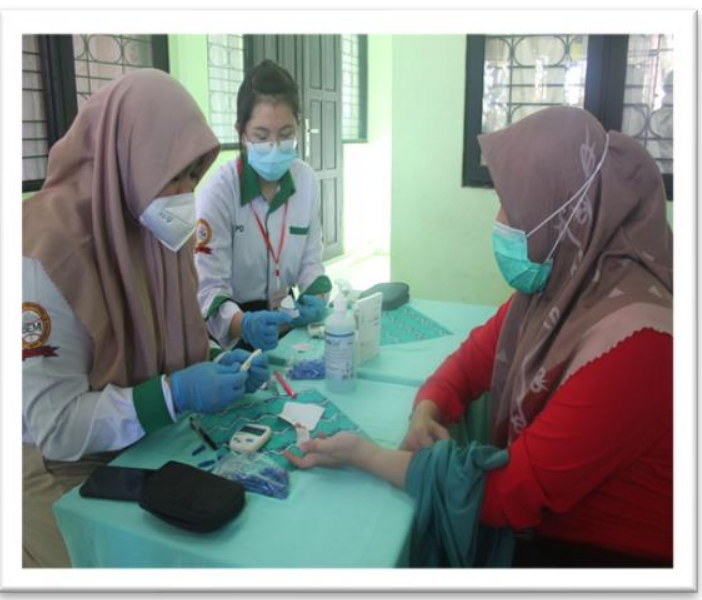

Sebelum dan setelah pemberian materi, peserta diminta mengisi pre-dan post-test yang berisi sejumlah pertanyaan untuk mengukur pengetahuan peserta mengenai personal hygiene.

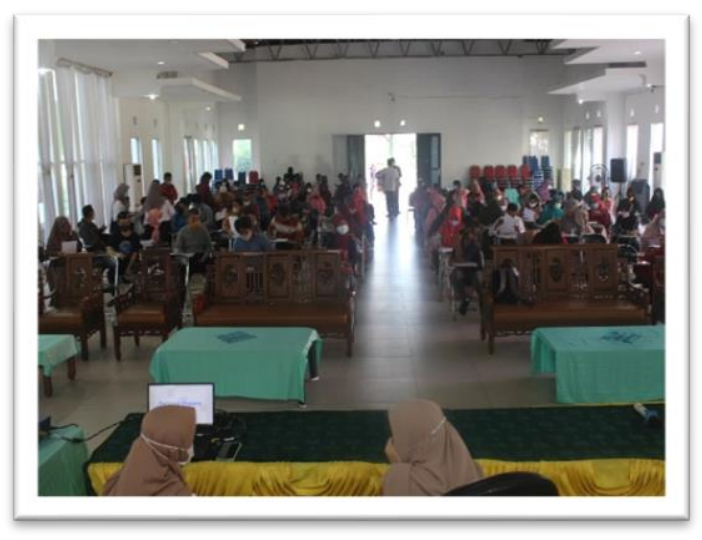

c. Materi esensial seminar

Pada kesempatan tersebut dr. Elma Rusida memberikan materi tentang kebersihan diri, terutama tentang pentingnya dan bagaimana membersihkan diri dengan baik dan benar. Penyaji menyampaikan tujuan kebersihan diri ialah untuk meningkatkan derajat kesehatan seseorang, pencegahan penyakit, dan meningkatkan kepercayaan diri seseorang.

Ada tujuh tips membersihkan diri yaitu menyikat gigi, menggunakan pakaian bersih, mencuci kaki, menjaga kebersihan rambut, membersihkan kuku, mencuci tangan dengan sabun, dan mandi dua kali sehari. Mencuci tangan pakai sabun sangat penting karena mencegah penularan virus corona. Mencuci tangan yang benar ialah dengan menggunakan sabun dan dengan air mengalir selama minimal 40-60 detik.

Cara untuk menjaga kebersihan diri adalah memakai cairan pembersih tangan berbasis alkohol dan jangan menggunakan pembersih tangan jika tangan terlihat kotor atau berminyak. Agar hasilnya efektif, cairan pembersih hendaknya mengandung alkohol dengan kadar minimal $60 \%$. Mandi dilakukan dengan memakai sabun dan air bersih dan dilakukan paling sedikit dua kali sehari. Sabun menetralkan kondisi asam yang melindungi kulit, menghilangkan minyak yang berlebihan, keringat, dan sel kulit mati.

Penggunaan sabun untuk anak harus yang berbahan lembut, berpelembab, dan tidak mengandung bahan kimia. Kebersihan diri yang tidak baik dapat meningkatkan penyakit seperti diare, demam berdarah dengue, cacingan, dan sebagainya. Keluarga sebagai tatanan pertama mempunyai peran dalam mengajarkan kebiasaan-kebiasaan tentang kebersihan diri 
untuk menumbuhkan kemandirian dalam diri anak.

Selain pemaparan materi, pada kegiatan tersebut juga diadakan diskusi dengan para peserta dan telah terlaksana dengan lancar. Para peserta fokus mendengarkan dan menyimak dengan baik. Para peserta juga aktif dalam bertanya dan berdiskusi. Jumlah penanya melebihi dari jumlah yang ditentukan. Waktu sesi tanya-jawab pun ditambah karena tingginya antusias peserta dalam bertanya. Sesi pemaparan materi berlangsung dengan tertib dan lancar tanpa adanya gangguan.

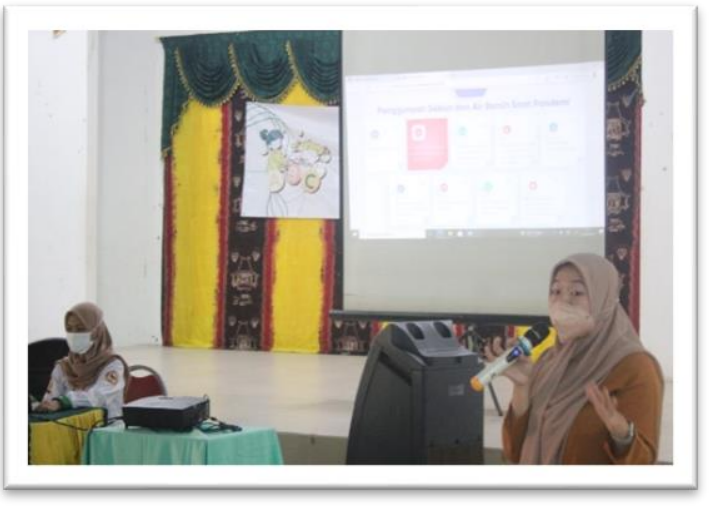

d. Pembuatan naskah berita untuk publikasi di media massa lokal

Setelah kegiatan dilaksanakan, tim abdimas melakukan analisis $5 \mathrm{~W}+1 \mathrm{H}$ dari kegiatan seminar pertama. Tim abdimas merangkum informasi kegiatan yang dibutuhkan yang bersumber dari notulensi dan dokumentasi kegiatan menjadi draft berita agar dapat terpublikasi di media massa. Kalimantan post adalah media cetak yang menjadi sasaran untuk publikasi kegiatan. Adapun link publikasinya adalah pada link beriku: https:// kalimantanpost.com/2021/09/pembinaanpersonal-hygiene-di-slb-c-negeri-pembina/

e. Rekap data hasil pre dan post test

Tim abdimas mengelola data pre- dan post-test untuk kemudian disajikan dalam laporan hasil akhir kegiatan abdimas sebagai informasi dalam penyajian hasil abdimas.

\section{PENGETAHUAN KEBIASAAN MENCUCI TANGAN DENGAN BENAR}

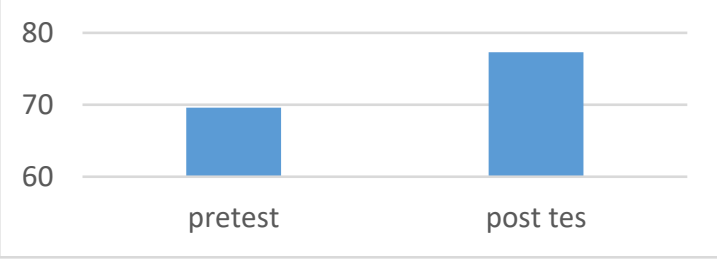

Setelah melakukan post-test ditemukan kenaikan yang sangat drastis dari pengetahuan peserta. Delapan orang yang meraih nilai 60 , lalu 19 orang meraih nilai 80 , dan 13 orang lainnya meraih nilai 100 . Sementara itu 5 orang sisanya meraih nilai kurang dari 60. Dapat disimpulkan $88 \%$ dari peserta post-test meraih nilai yang diharapkan. Ditemukan juga kenaikan nilai rata-rata skor dari 69,61 menjadi 77,3.

\section{SIMPULAN DAN SARAN}

Kegiatan pengabdian masyarakat ini meliputi, Pendekatan (Bonding) dengan Pihak Mitra, Tahap pra pelaksanaan kegiatan, tahap Pelaksanaan kegiatan, seminar pertama, predan post kegiatan, publikasi di media massa, pembuatan laporan kemajuan. Setelah kegiatan seminar terlaksana ditemukan adanya kenaikan nilai rata-rata skor pengetahuan dari 69,61 menjadi 77,3 . Adapun bagi tim abdimas selanjutnya yang akan membuat pengabdian di SLB sebaiknya mengangkat tema personal hygiene dengan memasukan pendekatan seni dan budaya lokal Kalsel

\section{UCAPAN TERIMAKASIH}

Kegiatan ini dibiayai oleh Universitas Lambung Mangkurat dengan Nomor SP DIPA023.17.2.677518/21 dengan Nomor Kontrak 272.50/UN8.2/AM/2021

\section{DAFTAR RUJUKAN}

Asterina, N., Beagen B., Hasanatun N., 2019. Kota Banjarmasin: Sebuah Profil Kota Ramah Disabilitas. Kantor UNESCO. Jakarta.

Pursitasari I, Allenidekania A, Agustini N. 2020. Appreciation Family Support and The Abilities of Children with Special Needs to Maintain Personal Hygiene: an Indonesian Case Study. Pediatric Reports. 12 (11):39-43.

Safaria, T., 2015. Autisme: Pemahaman Baru untuk Hidup Bermakna bagi Orang Tua. Graha IImu. Yogyakarta.

Teixeira SA, Santos PC, Batista AR, Albuquerque $\mathrm{BN}$, Vasconcelos $\mathrm{M}$, Borges-Oliveira AC. 2015. Assessment of oral hygiene in mentally disabled children. Revista Odonto Ciência. 30 (3): 65-70.

Triasmari U, Kusuma AN. 2019. Determinan Personal Hygiene Pada Anak Usia 912 Tahun. Faletehan Health Journal. 6 (1): 37-44.

Wanei, G.K. Sudarnoto, L.F.N., 2015. Survei Kebutuhan Guru Pembimbing Anak Autism Spectrum Disorder (ASD). Jurnal Psikoedukasi. 3 (3): 91-111. 
Bernstein, M. (2002). 10 tips on writing the living Web. A List Apart: For People Who Make Websites, 149. Retrieved from http://www.alistapart.com/articles 